\begin{tabular}{c|l|l|l}
$\begin{array}{c}\text { Case Reports in } \\
\text { NeUrology }\end{array}$ & $\begin{array}{l}\text { Case Rep Neurol 2011;3:75-81 } \\
\text { DOl: 10.1159/000324823 }\end{array}$ & $\begin{array}{l}\text { Published online: } \\
\text { February 23, 2011 }\end{array}$ & $\begin{array}{l}\text { O 2011 S. Karger AG, Basel } \\
\text { ISSN 1662-680X } \\
\text { www.karger.com/crn }\end{array}$ \\
\hline
\end{tabular}

\title{
Central Neurogenic Respiratory Failure: A Challenging Diagnosis
}

\author{
Flávio A. Carvalho ${ }^{\text {a }}$ Tenille Bernardino ${ }^{a}$ \\ Ricardo O.H. Maciel ${ }^{a}$ Sérgio F.A. Felizola ${ }^{b}$ \\ Eduardo L.V. Costac Gisele S. Silva a, b \\ aDepartment of Neurology and Neurosurgery, Federal University of São Paulo, \\ ${ }^{b}$ Neurology Program and Intensive Care Unit, Hospital Israelita Albert Einstein, \\ and 'Research and Education Institute, Hospital Sírio Libanês, Respiratory \\ Intensive Care Unit, University of São Paulo School of Medicine, São Paulo, Brazil
}

\section{Key Words}

Central neurogenic hyperventilation · Central apnea - Neurocritical care $\cdot$ Central respiratory failure

\begin{abstract}
Background: Central nervous system lesions are rare causes of respiratory failure. Simple observation of the breathing pattern can help localize the lesion, but the examiner needs to be aware of potential pitfalls such as metabolic or pulmonary alterations.

Methods: We describe 3 cases in which central neurogenic respiratory failure occurred simultaneously with other alterations or in an unusual presentation.

Results: All patients were diagnosed with central neurogenic respiratory failure and treated for it with good recovery.

Conclusion: Central neurogenic respiratory failure is a challenging diagnosis and needs to be reminded in difficult-to-wean patients carrying inconclusive evidences of metabolic or pulmonary alterations.
\end{abstract}

\section{Introduction}

Central nervous system lesions are rare causes of respiratory failure. In these cases, simple observation of the breathing pattern can help to localize the lesion, even though the examiner needs to be aware of the potential pitfalls caused by superimposed metabolic or pulmonary alterations [1].

There are 5 major alterations in breathing patterns due to neurologic conditions. The Cheyne-Stokes respiration is usually caused by bilateral forebrain impairment through a diffuse metabolic process or structural damage. True central neurogenic hyperventilation 
is rare and can presumably develop secondary to a lesion in the region of the parabrachial nucleus. Apneustic breathing generally occurs in the setting of pontine lesions and, at last, lesions in the ventrolateral medulla may cause ataxic breathing and apnea [1].

Our objective was to describe 3 cases in which some form of central neurogenic respiratory failure was suspected.

\section{Case Reports}

\section{Case 1}

A 22-year-old man with a history of type II neurofibromatosis presented to our service complaining of drowsiness and progressive difficulty to breathe during the last 4 months. On physical examination, he was drowsy, mildly confused, and tachypneic ( 52 breaths per minute) with rapid and shallow breathing showing marked asymmetric chest expansion (left greater than right). A chest X-ray revealed hemidiaphragmatic paralysis, and the study of his arterial blood gases (ABG) at room air showed a $\mathrm{pH}$ of 7.36, arterial oxygen tension $\left(\mathrm{PaO}_{2}\right)$ of $59.7 \mathrm{~mm} \mathrm{Hg}$, arterial $\mathrm{CO}_{2}$ tension $\left(\mathrm{PaCO}_{2}\right)$ of $62.3 \mathrm{~mm} \mathrm{Hg}$, and oxygen saturation $\left(\mathrm{SaO}_{2}\right)$ of $88.9 \%$. An MRI of the brain and spine disclosed bilateral schwannomas of the acoustic nerve with a significant brain stem compression (fig. 1). Surgery was performed with resection of the left tumor and after this procedure, the patient experienced a dramatic clinical and laboratorial improvement.

\section{Case 2}

A 42-year-old woman came to our hospital because of a 5-month history of progressive morning headache. A brain MRI revealed a compressive brain stem tumor which resulted in hydrocephalus and was surgically removed; a biopsy of the tumor specimen revealed an anaplastic glioma (fig. 2). The patient had 3 failed attempts of extubation at 3-day intervals. The first failure was attributed to an upper airway edema, for which she was treated with steroids. At that time, she was already off sedatives. After the last 2 extubation attempts, the respiratory therapists noticed that, while asleep, the patient experienced periods of prolonged apnea and oxygen desaturation not associated to breathing discomfort. These episodes did not occur while the patient was awake and she had no previous history of sleep apnea. After the third extubation attempt, a tracheostomy was performed, and she was gradually weaned from mechanical ventilation with no subsequent reports of loss of respiratory drive while asleep.

\section{Case 3}

A 64-year-old man was admitted to our hospital after a motor vehicle accident. At presentation, his neurological examination was normal. A head and neck CT showed a C4 fracture and a subluxation between C2 and C3. Twenty-four hours later, he complained of weakness and incoordination of the left hand, and a head and neck MRI/angio-MRI showed an ischemic stroke in the left cerebellar hemisphere and lateral medulla as well as a dissection of the left vertebral artery (fig. 3 ). He became somnolent and was intubated for airway protection. After 2 days, his ventilatory settings were minimal, with normal $\mathrm{ABG}$ values and no signs of neurologic decline. He was successfully extubated but $3 \mathrm{~h}$ later fell asleep, and his respiratory frequency dropped to 6 breaths per minute. His $\mathrm{SaO}_{2}$ was $90 \%$ and $\mathrm{ABG}$ as follows: $\mathrm{pH} 7.3, \mathrm{PaO}_{2} 88 \mathrm{~mm} \mathrm{Hg}$, and $\mathrm{PaCO}_{2} 50 \mathrm{~mm} \mathrm{Hg}$. He woke up at the time of ABG collection and his respiratory rate went back to 12 breaths per minute. Four hours later, again during sleep, his respiratory rate went down to 4 breaths per minute; he became somnolent and was re-intubated. A repeat head CT did not show any new lesions. The patient remained on minimal ventilatory support for several days, which was adequate while awake but led to a low tidal volume and a decreased respiratory frequency during sleep. A tracheostomy was then performed, and a positive-pressure ventilation device was offered at night for 2 weeks. His breathing pattern spontaneously improved and he was discharged home. 


\begin{tabular}{l|l|l|l}
$\begin{array}{c}\text { Case Reports in } \\
\text { NeUlology }\end{array}$ & $\begin{array}{l}\text { Case Rep Neurol 2011;3:75-81 } \\
\text { DOI: 10.1159/000324823 }\end{array}$ & $\begin{array}{l}\text { Published online: } \\
\text { February 23, 2011 }\end{array}$ & $\begin{array}{l}\text { O 2011 S. Karger AG, Basel } \\
\text { ISSN 1662-680X } \\
\text { www.karger.com/crn }\end{array}$ \\
\hline
\end{tabular}

\section{Discussion}

Here, we reported 3 cases of hypothetical respiratory failure associated with central nervous system lesions. We often face similar cases in our practice; yet, the diagnosis of central neurogenic respiratory failure is usually overlooked due to the presence of confounding factors such as metabolic and pulmonary disorders.

Breathing integrates almost every level of the brain and upper spinal cord and is regulated voluntarily through cortical inputs and by medullary and pontine reflex neural mechanisms. In this sense, it can be disrupted by brain stem lesions or metabolic disorders [1].

Patient 1 had a rapid and shallow pattern of breathing which resulted in an inadequate gas exchange with an elevated $\mathrm{PaCO}_{2}$ and a low $\mathrm{PaO}_{2}$ despite an increased respiratory rate. After tumor resection, he experienced sustained improvement. If isolated central neurogenic hyperventilation had occurred, a drop in the $\mathrm{PaCO}_{2}$ with a high $\mathrm{pH}$ and normal or high $\mathrm{PaO}_{2}$ was to be expected [2]; therefore, a mixed cause is a reasonable explanation for this case.

In patient 2 , the upper airway edema was confirmed visually as the cause of the first extubation failure. An associated neurogenic cause, possibly Ondine's curse, was suspected only after the third extubation failure. Ondine's curse was originally described as a primary alveolar hypoventilation syndrome occurring after bilateral ventrolateral high cervical cordotomy $[3,4]$. Patients with Ondine's curse are no longer capable of spontaneously breathing and must consciously and voluntarily force themselves to breathe. This syndrome has been reported in a few patients with acute vertebrobasilar strokes, medullary tumors, and other structural lesions [5-7].

Patient 3 may be considered a classical case of loss of automatic breathing associated with a medullary stroke. Therapeutic symptomatic options range from pharmacologic approaches [5] and use of bilevel positive airway pressure to implantation of diaphragmatic pacemaker $[8,9]$. As was seen in patients 2 and 3 , spontaneous recovery can occur [10].

In each case, central nervous system lesions allegedly contributed to the patients' respiratory distress and might have gone unnoticed if not for a high degree of suspicion. In conclusion, our patients are examples for the need of thinking of centrally mediated respiratory failure as differential diagnoses in difficult-to-wean patients, when history and physical examination suggest conditions affecting the brain stem.

\section{Disclosure Statement}

No support was given from any source. 


\begin{tabular}{l|l|l|l}
$\begin{array}{c}\text { Case Reports in } \\
\text { NeUlology }\end{array}$ & $\begin{array}{l}\text { Case Rep Neurol 2011;3:75-81 } \\
\text { DOI: 10.1159/000324823 }\end{array}$ & $\begin{array}{l}\text { Published online: } \\
\text { February 23, 2011 }\end{array}$ & $\begin{array}{l}\text { O 2011 S. Karger AG, Basel } \\
\text { ISSN 1662-680X } \\
\text { www.karger.com/crn }\end{array}$ \\
\hline
\end{tabular}
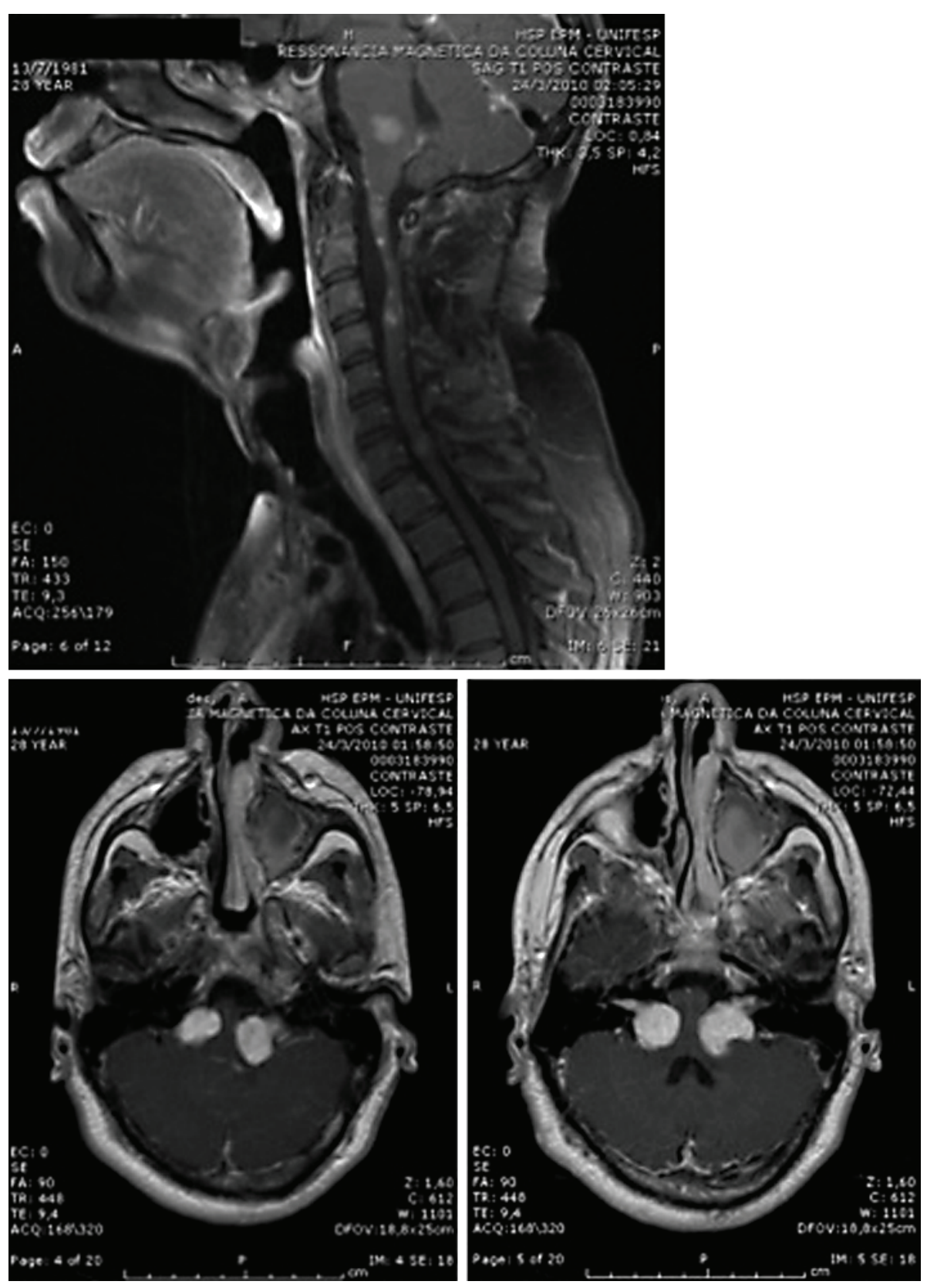

Fig. 1. Cervical and brain MRI showing scattered spinal neurofibromas and bilateral schwannomas of the acoustic nerve. 


\begin{tabular}{c|l|l|l}
$\begin{array}{c}\text { Case Reports in } \\
\text { NeUlology }\end{array}$ & $\begin{array}{l}\text { Case Rep Neurol 2011;3:75-81 } \\
\text { DOI: 10.1159/000324823 }\end{array}$ & $\begin{array}{l}\text { Published online: } \\
\text { February 23, 2011 }\end{array}$ & $\begin{array}{l}\text { O 2011 S. Karger AG, Basel } \\
\text { ISSN 1662-680X } \\
\text { www.karger.com/crn }\end{array}$ \\
\hline
\end{tabular}
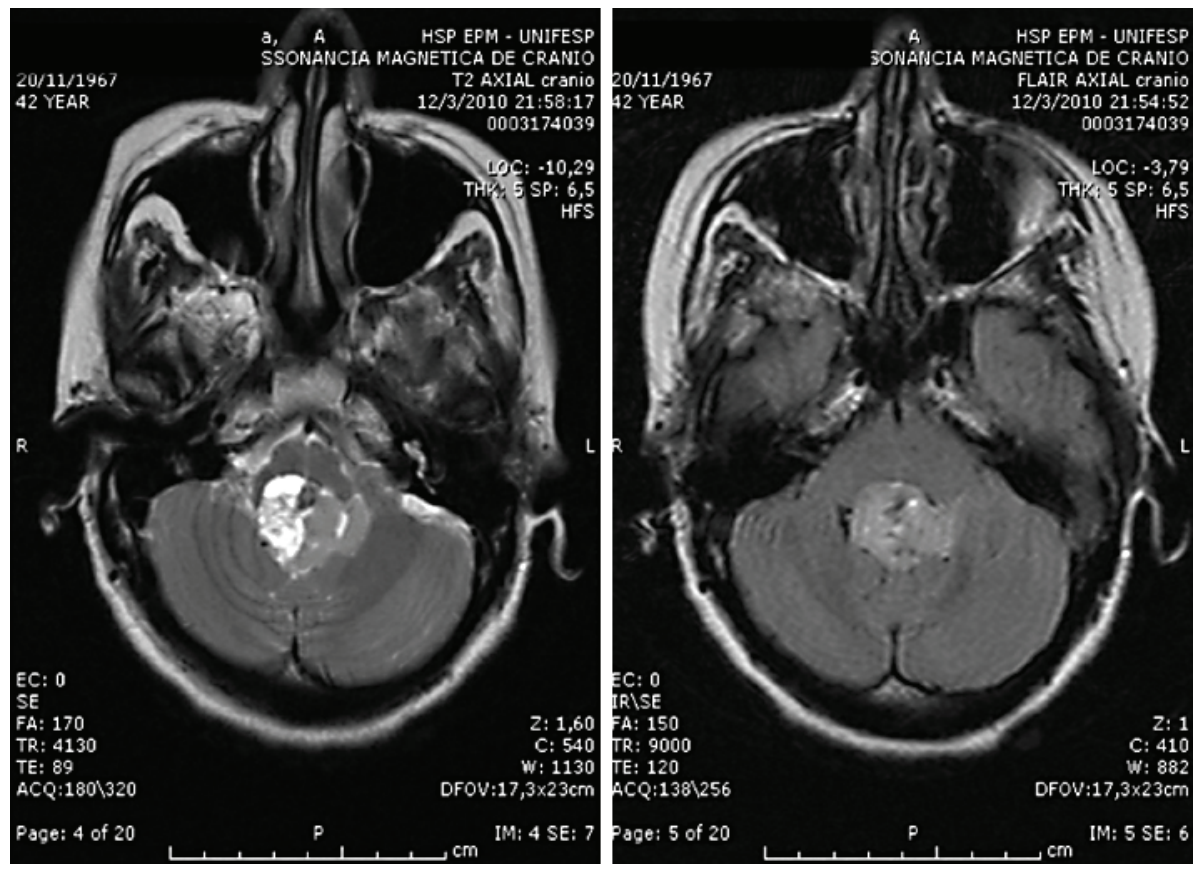

Fig. 2. T2 and FLAIR sequences showing a brain stem tumor invading the fourth ventricle. Biopsy revealed an anaplastic glioma. 


\begin{tabular}{c|l|l|l}
$\begin{array}{c}\text { Case Reports in } \\
\text { Neurology }\end{array}$ & $\begin{array}{l}\text { Case Rep Neurol 2011;3:75-81 } \\
\text { DOI: 10.1159/000324823 }\end{array}$ & $\begin{array}{l}\text { Published online: } \\
\text { February 23, 2011 }\end{array}$ & $\begin{array}{l}\text { O 2011 S. Karger AG, Basel } \\
\text { ISSN 1662-680X } \\
\text { www.karger.com/crn }\end{array}$ \\
\hline
\end{tabular}
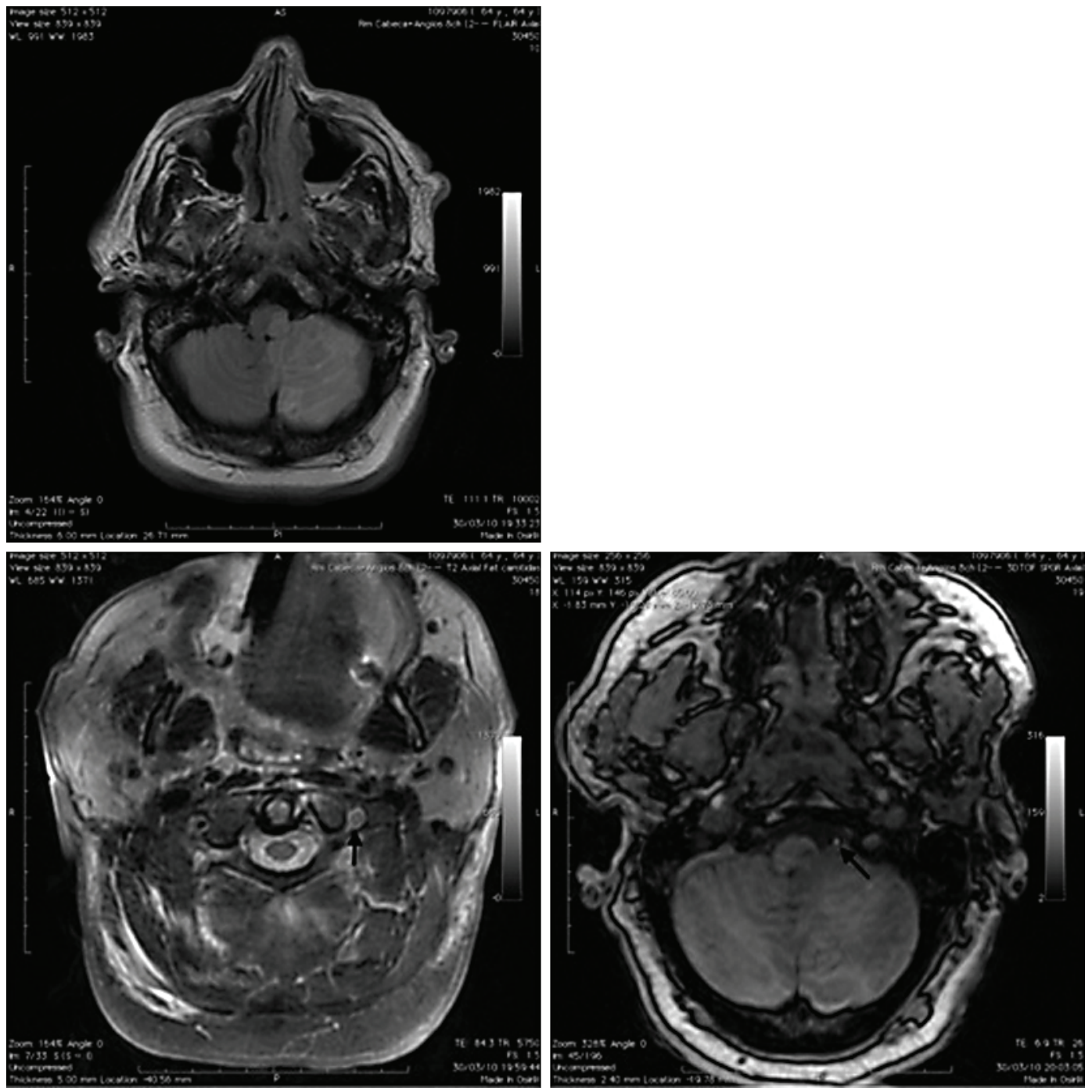

Fig. 3. Left medullary and cerebellar ischemia caused by dissection of the left vertebral artery (arrows). 


\begin{tabular}{c|l|l|l} 
Case Reports in & Case Rep Neurol 2011;3:75-81 & $\begin{array}{l}\text { Published online: } \\
\text { February 23, 2011 }\end{array}$ & $\begin{array}{l}\text { ○ 2011 S. Karger AG, Basel } \\
\text { ISSN 1662-680X } \\
\text { www.karger.com/crn }\end{array}$ \\
\hline
\end{tabular}

\section{References}

1 Posner JB, Saper CB, Schiff ND, Plum F: Examination of the comatose patient; in Posner JB, Saper CB, Schiff ND, Plum F (eds): Plum and Posner's Diagnosis of Stupor and Coma, 4th ed. New York, Oxford University Press, 2007, pp 38-87.

2 Ducros L, Vahedi K, Similowski T, Bousser MG, Payen D: Uncontrollable high-frequency tachypnea in a case of unilateral medial medullary infarct. Intensive Care Med 2003;29:841-844.

3 Severinghaus JW, Mitchell RA: Ondine's curse - failure of respiratory center automaticity while awake. Clin Res 1962;10:122.

4 Kuhn M, Lütolf M, Reinhart WH: The eye catcher. Ondine’s curse. Respiration 1999;66:265.

5 Pedroso JL, Baiense RF, Scalzaretto AP, Neto PB, Teixeira de Gois AF, Ferraz ME: Ondine's curse after brainstem infarction. Neurol India 2009;57:206-207.

-6 Auer RN, Rowlands CG, Perry SF, Remmers JE: Multiple sclerosis with medullary plaques and fatal sleep apnea (Ondine's curse). Clin Neuropathol 1996;15:101-105.

7 Marin-Sanabria EA, Kobayashi N, Miyake S, Kohmura E: Snoring associated with Ondine's curse in a patient with brainstem glioma. J Clin Neurosci 2006;13:370-373.

8 Kapnadak SG, Mikolaenko I, Enfield K, Gress DR, Nathan BR: Ondine's curse with accompanying trigeminal and glossopharyngeal neuralgia secondary to medullary telangiectasia. Neurocrit Care 2010;12:395-399.

9 Chervin RD, Guilleminault C: Diaphragm pacing for respiratory insufficiency. J Clin Neurophysiol 1997;14:369-377.

10 Schestatsky P, Fernandes LNT: Acquired Ondine's curse: case report. Arq Neuropsiquiatr 2004;62:523-527. 